\author{
Marquette University \\ e-Publications@Marquette
}

School of Dentistry Faculty Research and

Publications

Dentistry, School of

6-2016

\title{
Three-Dimensional Bioprinting Materials with Potential Application in Preprosthetic Surgery
}

\author{
Mina D. Fahmy \\ Marquette University \\ Hossein E. Jazayeri \\ Marquette University \\ Mehdi Razavi \\ Brunel University \\ Radi Masri \\ University of Maryland at Baltimore \\ Lobat Tayebi \\ Marquette University, lobat.tayebi@marquette.edu
}

Follow this and additional works at: https://epublications.marquette.edu/dentistry_fac

Part of the Dentistry Commons

\section{Recommended Citation}

Fahmy, Mina D.; Jazayeri, Hossein E.; Razavi, Mehdi; Masri, Radi; and Tayebi, Lobat, "Three-Dimensional Bioprinting Materials with Potential Application in Preprosthetic Surgery" (2016). School of Dentistry Faculty Research and Publications. 184.

https://epublications.marquette.edu/dentistry_fac/184 


\title{
Three-Dimensional Bioprinting Materials with Potential Application in Preprosthetic Surgery
}

\author{
Mina D. Fahmy \\ School of Dentistry, Department of Developmental Sciences, \\ Marquette University, \\ Milwaukee, WI \\ Hossein E. Jazayeri \\ School of Dentistry, Department of Developmental Sciences, \\ Marquette University, \\ Milwaukee, WI \\ School of Dental Medicine, University of Pennsylvania, \\ Philadelphia, PA \\ Mehdi Razavi \\ BCAST, Institute of Materials and Manufacturing, \\ Brunel University London, \\ Uxbridge, London, UK. \\ Brunel Institute for Bioengineering, Brunel University London, \\ Uxbridge, London, UK
}


NOT THE PUBLISHED VERSION; this is the author's final, peer-reviewed manuscript. The published version may be accessed by following the link in the citation at the bottom of the page.

\author{
Radi Masri \\ Department of Endodontics, Prosthodontics and Operative \\ Dentistry, University of Maryland School of Dentistry, \\ Baltimore, $M D$ \\ Lobat Tayebi \\ School of Dentistry, Department of Developmental Sciences, \\ Marquette University, \\ Milwaukee, WI \\ Department of Engineering Science, University of Oxford, \\ Oxford, UK
}

We acknowledge the grant from Marquette strategic Innovation fund (3D Printing of Customized Implants for Cleft Lip, Palate and Orofacial Deformities and Defects).

Supported in part by the National Science Foundation (NSF, Grant no.CMMI1363485) and Marquette University Strategic Innovation Fund.

The authors deny any conflicts of interest.

\begin{abstract}
Current methods in handling maxillofacial defects are not robust and are highly dependent on the surgeon's skills and the inherent potential in the patients' bodies for regenerating lost tissues. Employing custom-designed 3D printed scaffolds that securely and effectively reconstruct the defects by using tissue engineering and regenerative medicine techniques can revolutionize preprosthetic surgeries. Various polymers, ceramics, natural and synthetic bioplastics, proteins, biomolecules, living cells, and growth factors as well as their hybrid structures can be used in 3D printing of scaffolds, which are still under development by scientists. These scaffolds not only are beneficial due to their patient-specific design, but also may be able to prevent micromobility, make tension free soft tissue closure, and improve vascularity. In this manuscript, a review of materials employed in 3D bioprinting including bioceramics, biopolymers, composites, and metals is conducted. A discussion of the relevance of 3D bioprinting using these materials for craniofacial interventions is included as well as their potential to create analogs to craniofacial tissues, their benefits, limitations, and their application.
\end{abstract}

Three-dimensional (3D) printing, or additive manufacturing (AM), was first used by Charles Hull in 1986 to sequentially form a 3D structure using layered light-cured material. $\frac{1}{-}$ Initially, 3D printing was not used for biological applications but was employed for the deposition of metals and ceramics, which was not conducive to living

Journal of Prosthodontics, Vol 25, No. 4 (June 2016): pg. 310-318. DOI. This article is @ Wiley and permission has been granted for this version to appear in e-Publications@Marquette. Wiley does not grant permission for this article to be further copied/distributed or hosted elsewhere without the express permission from Wiley. 
cells. Thus, a challenge with 3D bioprinting is finding suitable biocompatible materials while also providing the mechanical and functional properties for maintaining the tissue. $\underline{2}$ Three-dimensional bioprinting is a relatively new and emerging field in which advances have led to the printing of biocompatible materials for the production of medical devices as well as the replacement of human tissues and organs. $\frac{3,4}{}$ During 3D bioprinting, biological materials and reagents are placed in precise cross-sectional layers from the bottom. $2,5,6$ The process begins with a 3D model, which is created by a computer-aided design (CAD) software. Cross-sectional slices are then taken of the model and sent to the AM device, which ultimately deposits each layer to produce the object. $\underline{5}$ Compared to conventional techniques in which several parts are assembled, in 3D bioprinting the final product can be produced in a single process, leading to a reduction in time and cost. In addition, design files may be transferred electronically and retained indefinitely, unlike conventional technology where designs are difficult to share and physical prototypes occupy space. $\frac{5}{}$ Furthermore, 3D printing provides more efficient use of raw materials and limits the amount of needed energy for the production process. $\underline{5}$

There are numerous approaches to a 3D bioprinting process, including cell types, printing techniques, and materials selection. As noted by Murphy and Atala, materials must have appropriate crosslinking mechanisms to allow for proper deposition and biocompatibility over the long term. ${ }^{2}$ In addition, it is imperative that materials support the proliferation of cells, as well as cellular function and attachment. ${ }^{7}$ Although the future of this profound and expanding technology is uncertain, it is expected to revolutionize the manufacturing industry, in turn benefiting numerous fields, including the medical and dental realm.

In this review, different commonly used biomaterials in 3D printing are explored, along with a discussion of their advantages and disadvantages. The applications of 3D bioprinting in dentoalveolar repair due to maxillofacial injury, disease, pathology, or trauma are also discussed in conjunction with the use of scaffolds.

Journal of Prosthodontics, Vol 25, No. 4 (June 2016): pg. 310-318. DOI. This article is (C) Wiley and permission has been granted for this version to appear in e-Publications@Marquette. Wiley does not grant permission for this article to be further copied/distributed or hosted elsewhere without the express permission from Wiley. 
NOT THE PUBLISHED VERSION; this is the author's final, peer-reviewed manuscript. The published version may be accessed by following the link in the citation at the bottom of the page.

\section{Clinical applications}

Three-dimensional bioprinting using CAD data for the creation of a model has been used in numerous areas of medicine. As noted by Vorndran et al, AM has the advantage of allowing for the fabrication of biologic implants from computer tomography (CT) data specific to the patient. .8 Autografts and allografts have been used in reconstructive surgery to treat several craniofacial anomalies and abnormalities. .9 Although autografting is considered the gold standard because graft material contains live cells and growth factors, this process can be highly invasive and may cause donor site morbidity as well as extended hospital stays. $\frac{10,11}{1}$ Allografts are not invasive to the patient, but there are several ethical concerns as well as concerns regarding contamination. 12 Common to both procedures is that the graft must be manually shaped to precisely fit the defect during surgery, possibly leading to inaccuracies and lack of superior esthetics. $\frac{13}{3}$ Threedimensional bioprinting technology allows for the fabrication of artificial grafts that may be superior to both autografts and allografts in adaptation, safety, and invasiveness. $\underline{14}$ Desired characteristics of 3D printed biomaterials include biocompatibility and osteoconductivity..$\underline{15}$ Porosity is also an important factor to allow for tissue in-growth, vessel formation, and conveyance of nutrition to the newly produced tissues. $\frac{16-18}{}$ Moreover, customizability of shape, size, orientation, and pore connectivity is vital to ensure that the envelope of soft tissue covering the affected bone is esthetically acceptable, while still allowing for the scaffold to restore initial functionality. ${ }^{15,19}$

Due to congenital abnormalities, cancerous growths, and traumatic injuries, the management of tissue loss has been a topic of study in the surgical realm. Several materials, including bioceramics, biopolymers, composites, and metals, have been reported in the literature and may be used to make customized 3D scaffolds for use in dentoalveolar defect repair. These materials will be discussed and reviewed in the following sections.

\section{Materials used for 3D bioprinting}

\section{Bioceramics}

Journal of Prosthodontics, Vol 25, No. 4 (June 2016): pg. 310-318. DOI. This article is @ Wiley and permission has been granted for this version to appear in e-Publications@Marquette. Wiley does not grant permission for this article to be further copied/distributed or hosted elsewhere without the express permission from Wiley. 
NOT THE PUBLISHED VERSION; this is the author's final, peer-reviewed manuscript. The published version may be accessed by following the link in the citation at the bottom of the page.

\section{Calcium phosphate}

Calcium phosphate compounds have been used because of their ability to chemically bond to hard tissue. 20 Tricalcium phosphate (TCP) exists as three polymorphs, including the less dense but more soluble monoclinic $a$ and hexagonal $a^{\prime}$, and the higher density, rhombohedral $\beta$ form. ${ }^{21}$ The $a$ and $a^{\prime}$ forms are formed at high temperatures and can be converted from the $\beta$ state between 1100 and $1200^{\circ} \mathrm{C}$, whereas a conversion from $\beta$ to a involves slow cooling. $\underline{22}$ TCP ceramics have been shown to exhibit more biodegradability than other material candidates including hydroxyapatite (HA). $\underline{23}$ Lacefield has found that bone formation is aided by the release of $\mathrm{Ca}$ and $\mathrm{PO}_{4}$ ions near the implant. $\underline{24}$ Klein et al noted that in comparison to HA coatings, a-TCP induced greater amounts of bone remodeling within the first week of implantation. ${ }^{25}$ TCP materials slowly resorb in physiological conditions and may be molded into the defects in granule form; however, these granules can only be placed into the defects surrounded by intact bone. Conversely, calcium phosphate cements (CPC) can be molded freely and will provide necessary mechanical soft tissue support after hardening. Despite this advantage, the use of CPC is limited due to lack of macroporosity. Custom-made calcium phosphate implants with a defined structure for precise patient fitting have been designed to circumvent the issue of lack of macroporosity. ${ }^{26} \beta$-TCP is the most favorable form of TCP due to its mechanical strength and chemical stability, although there are several challenges associated with it including maintaining a low sintering temperature so as to avoid a transformation to a-TCP. .77 Miranda et al note that $\beta$-TCP scaffolds containing a 3D network of rods have been designed by direct-write assembly, while optimization of $\beta$-TCP printing materials has been investigated. $\underline{28}$

\section{Hydroxyapatite}

Because of the stoichiometric similarity to the mineral phase of natural bone, HA has been deemed a bone replacement with good potential for biocompatibility. $\frac{29,30}{\mathrm{HA}}$ implants have been assembled by means of numerous techniques, including hydrothermal conversion, 31 use of polymer sponges, $\underline{32}$ and bulk ceramic processing techniques. $\underline{33}$ However, all of these methods are limited in ability to control the implant's porosity. Several methods have been recently developed to

Journal of Prosthodontics, Vol 25, No. 4 (June 2016): pg. 310-318. DOI. This article is @ Wiley and permission has been granted for this version to appear in e-Publications@Marquette. Wiley does not grant permission for this article to be further copied/distributed or hosted elsewhere without the express permission from Wiley. 
allow for the controlled design and engineering of 3D HA scaffolds. The stereolithography (SLS) technique has been used to build HA scaffolds using the lost-mold technique. $\frac{34}{}$ In addition, direct-write assembly using colloidal inks with tailored viscoelastic properties was also used for the construction of 3D HA scaffolds. $\frac{35,36}{3 i c h n a}$ et al have developed HA scaffolds with the desired characteristics by customizing their architecture and sintering conditions using HA printing material suitable for direct-write assembly. ${ }^{37}$ Chumnanklang et al described how adhesive binder could be incorporated by means of two methods in the preparation of HA powder: either mixing as separate grains or coating the HA powder. $\frac{38}{2}$ Leukers et al used HA granules to create ceramic porous constructions. A patient's own cells may be seeded onto the scaffold for tissue engineering. Leukers et al noted that the produced scaffolds can act as 3D templates for primary cell attachment, which is followed by tissue formation. $\frac{39}{\text { Irsen et al }}$ emphasized that HA granulates may not fulfill all of the necessary requirements for use in $3 \mathrm{D}$ printing because $\mathrm{HA}$ is expensive, and does not optimally interact with binder liquid. Optimization of bioprinting techniques is required to attain good surface quality in addition to achieving better resolution. $\underline{40}$

\section{Bioglass}

Bioactive glasses (BG) have shown great potential in both the healing and regeneration of bone defects because of their ability to support osteoblast cells, and to bond to both soft and hard tissue. 11,42 $B G$ is an attractive alternative for other scaffold materials because of its ability to stimulate angiogenesis in the presence of vascular endothelial growth factor (VEGF). $\frac{43}{B G}$ displays characteristics of osteoconductivity and oseteoproductivity; both are features that improve the proliferation and differentiation of progenitor cells. $\frac{44}{A n}$ important feature of BG is development of a biologically active surface layer of $\mathrm{HA}$ and carbonated hydroxyapatite ( $\mathrm{CHA}$ ) allowing for interfacial bonding to surrounding tissues without scar layer formation. $\frac{45,46}{4}$ However, BG does not usually degrade at a quick enough rate and thus may remain within the body for an extended time. $\frac{47}{}$ A concern with using porous BG scaffolds is their cytotoxicity on the surrounding environment, perhaps caused by high ion concentration. $\underline{48}$

Journal of Prosthodontics, Vol 25, No. 4 (June 2016): pg. 310-318. DOI. This article is (C) Wiley and permission has been granted for this version to appear in e-Publications@Marquette. Wiley does not grant permission for this article to be further copied/distributed or hosted elsewhere without the express permission from Wiley. 
The advantage of using ceramics such as HA, bioglass, and calcium phosphate is that they can upregulate osteogenesis. Another advantage is their ability to allow for space maintenance, making them materials of interest in reconstruction of craniofacial defects. $\underline{49}$ Bioceramic-printed scaffolds allow for rapid population of the cells onto the scaffold surface as well as promoting the proliferation of cells; however, ceramics are too brittle to allow for implantation in loadbearing craniofacial sites (i.e., implants designed to restore or replace the temporomandibular joint $[\mathrm{TMJ}]) . \underline{50}$

\section{Biopolymers}

\section{Alginate}

Alginate is a water-soluble polysaccharide with properties similar to the native extracellular matrix, so it is effective in tissueengineering applications. Alginate has profound implications on cartilage repair as a potent hydrogel, and it is widely understood that alginate is extremely compatible with cartilaginous tissue..$\underline{51,52}$ Cell encapsulation of alginate in biomedical applications has proven to be effective due to its support of surrounding chondrocytes. $\underline{53}$ Furthermore, alginate induces chondrocyte proliferation. $\frac{52}{\text { The }}$ morphology of chondrocytes becomes more easily rounded by the material, and the mechanical properties of alginate continue to make it a desirable substance in tissue regeneration. $\frac{54}{4}$ Alginate gel has the capacity to allow for surrounding tissue resistance upon implantation until precursor stem cells migrate to the area and differentiate into chondrocytes. $\underline{55}$

Additionally, 3D alginate constructs have been frequently used to induce differentiation of human mesenchymal stem cells for fibrocartilage repair and for their ability to induce cell expansion. Alginate is much more effective when combined with another compound, such as chitosan or polylactide, because of its mechanical vulnerability and degradability by rapid ion exchange. $\underline{56}$ Alginate can be molded and injected, and these properties also make it an attractive candidate for TMJ cartilage engineering applications. $\frac{57,58}{}$ The hydrophilic characteristics of alginate enhance its biocompatibility, and it promotes osteocyte growth and works synergistically with growth

Journal of Prosthodontics, Vol 25, No. 4 (June 2016): pg. 310-318. DOI. This article is @ Wiley and permission has been granted for this version to appear in e-Publications@Marquette. Wiley does not grant permission for this article to be further copied/distributed or hosted elsewhere without the express permission from Wiley. 
factors, such as vascular endothelial growth factor (VEGF), to repair defected bone. $\underline{59}$

A limitation of alginate is that it frequently does not interact with cells and proteins. As stated above, it is necessary for alginate to be combined in a scaffold with another compound that increases its cell attachment capabilities to optimize regeneration of the tissue. $\frac{60}{}$ Although hydrogels, like alginate, generally promote regeneration, they are not suitable for load-bearing applications. $\underline{59}$ Hydrogels have been said to have the ability of exposing cells to environments that are very hydrated and resemble natural ECM; however, hydrogels also present with a very low stiffness characteristic relative to most loadbearing tissues in the maxillofacial region. $\underline{50}$ Thus, printing scaffolds for the regeneration of tissues required to sustain higher mechanical forces for craniofacial defects requires the use of other materials, including ceramics or composites. $\underline{61}$

\section{Biogenic polyphosphate}

Biogenic polyphosphates (bio-polyP) have been used to create porous scaffolds for tissue engineering. They have been studied frequently for their prominence in scaffold implantation because of their reputable biocompatibility. $\underline{62}$ Bioprinted bio-polyP scaffolds have remarkable resolution, and their immediate fabrication requires no further processing, unlike other methods. $\underline{63}$ Bio-polyP not only increases the release of bone morphogenetic protein 2 and accelerates bone mineralization, but also inhibits the differentiation of osteoclastic precursors into osteoclasts, preserving the integrity of bone and

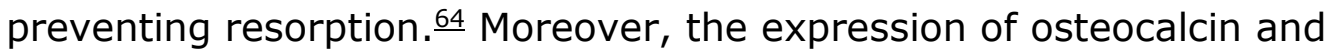
osterix, proteins involved in osteoblast differentiation, is increased. $\underline{65}$ The purpose of using bio-polyP is to stimulate the inductive role of the native, healthy extracellular matrix present prior to the onset of disease or trauma. $\underline{66}$ Bio-polyP is an ideal polymer for use in scaffolds for bone regeneration because it can be hardened after printing. Its inductive activity makes it favorable as it stimulates osteocytes to undergo an anabolic process that results in HA formation. $\underline{64}$ The influence of polyphosphate on bone repair is profound, because it regulates scaffold porosity and increases its osteoconductivity. $\underline{67}$ Newly formed natural bone can then grow within the scaffold. $\underline{68}$ The ideal matrix environment can be mimicked by the polymer's vast 
morphogenetic capabilities. Moreover, bio-polyP can play a role in regulating organismic hemostasis, affecting the body's coagulation cascade. $\underline{69}$ Precisely fitting, patient-specific scaffolds can be designed with these types of materials to ensure a cost-effective and lasting treatment solution. $\frac{15}{}$ It remains unknown in which form bio-polyP stimulates bone mineralization, in a polymeric state or monomeric phosphates resulting from hydrolytic breakdown. $\underline{64}$ Craniomaxillofacial (CMF) bone defects, with the aid of CAD/CAM software, can be repaired with bio-polyP, among many other biocompatible materials, in scaffold fabrication and implantation. $\underline{70}$

\section{Biogenic silica}

Biogenic silica (BSi) shares very similar properties and invokes nearly identical biochemical action to bio-polyP. Both materials are morphogenetically active and are incredibly resistant to non-favorable environmental conditions. $\underline{11}$ The complex architecture of a BSi network and its strong opto-mechanical properties allow it to be exceptionally potent in nanomedicine and bone repair. $\underline{72}$ The porosity of the scaffold influenced by the use of BSi allows for effective nutrient diffusion, which is essential for much of the avascular hard tissue composing the majority of the craniofacial skeleton. BSi is routinely used in nanoparticle form and has recently been applied to bone regeneration studies. $\underline{73}$ The use of the mentioned nanomaterials significantly increases the expression of collagen type I. $\frac{74}{B S i}$ has proven to be effective by stimulating the mineralization of SaOS-2 cell line, a type of cell similar to osteoblasts, in vitro. It also regulates the concentration of osteoprotegerin, which plays a role in bone resorption. $\underline{75}$ The printing of cells into a scaffold has not yet made great strides, but the demonstration of an alginate scaffold complex containing osteoblasts has been effective in allowing those bone cells to proliferate only if $\mathrm{BSi}$ is added to induce the process. $\frac{65}{}$ The ability of $\mathrm{BSi}$ to be absolutely essential in the mineralization of hard tissue makes it a quality candidate for printing applications, especially in maxillofacial trauma cases. $\frac{76}{}$ Its trabecular architecture is favorably shaped by silica to allow for optimal biocompatibility. $\underline{\text { Im }}$ Imersing the material in a layer of body fluid forms a layer similar to maxillofacial hard tissue, and its variation in pore size makes it very applicable for drug delivery systems and tissue-engineering cases. $\underline{78}$ Its high surface

Journal of Prosthodontics, Vol 25, No. 4 (June 2016): pg. 310-318. DOI. This article is (C) Wiley and permission has been granted for this version to appear in e-Publications@Marquette. Wiley does not grant permission for this article to be further copied/distributed or hosted elsewhere without the express permission from Wiley. 
charge density attracts proteins to its surface and has been thought to positively affect cell adhesion to the scaffold complex. $\underline{79}$

Furthermore, it is beneficial that BSi does not disrupt calcium concentration or $\mathrm{pH}$ levels. $\frac{80}{}$ The pore size of the silica-based scaffold affects the rate of nucleation as well, enhancing the bioactivity of the material. There was no mention of disadvantages in using biogenic silica for scaffold preparation and delivery to treat bone defects; it is very suitable for hard-tissue engineering. $\underline{64}$ Prosthetic applications and microsphere drug conveyance benefit from the research of silica properties and overall effect, while researchers deduce that it holds great promise in nanomedicine applications. $\underline{81}$

\section{Composites}

A number of biopolymers have been considered for bone tissue engineering applications; however, no sole polymer is able to satisfy all the necessities for a bone graft material. To overcome the problems involving individual materials, composite materials have been recently developed, given that natural bone is an organic/inorganic hybrid composed of collagen and apatites. $\frac{6,82}{}$ Polymer/ceramic composites contain the appropriate properties of each individual component, including the high wear resistance of ceramics and high toughness of polymers. This knowledge also allows for manufacturing of biphasic porous scaffolds to regenerate damaged tissues such as the TMJ. $\frac{83}{3}$

\section{Calcium phosphate/collagen}

3D bioprinting under low temperatures allows for the production of composites with synthetic or natural polymers such as collagen. Adding collagen into mineralized bone cements could improve their mechanical characteristics in addition to their bioactive properties. $\underline{83}$

Inzana et al $\underline{83}$ assessed the possibility of using low-temperature 3D bioprinting for production of collagen-calcium phosphate composite by dissolving collagen into phosphoric acid as a binder solution. Highresolution inkjet printing of collagen has not been previously used in 3D printing of calcium phosphates. This research showed the possibility of using high-resolution inkjet printing of collagen in 3D printing of calcium phosphates and its effect on the mechanical and

Journal of Prosthodontics, Vol 25, No. 4 (June 2016): pg. 310-318. DOI. This article is @ Wiley and permission has been granted for this version to appear in e-Publications@Marquette. Wiley does not grant permission for this article to be further copied/distributed or hosted elsewhere without the express permission from Wiley. 
cellular characteristics of collagen inclusion in vitro. Adding collagen into the phosphoric acid binder solution notably enhanced the strength of the 3D printed calcium phosphate as a linear function of collagen concentration. In vitro cell culture experiments confirmed the viability of $\mathrm{C} 3 \mathrm{H} / 10 \mathrm{~T} 1 / 2$ cells cultured on the scaffold materials for about 72 hours. In comparison to previous studies on printing collagen for production of a fibrous network, $\underline{84}$ in this research the viscous solution of collagen was printed by a DC solenoid inkjet valve with a larger diameter. Moreover, in vivo studies showed that the 3D printed scaffolds encouraged new bone growth into the pores as they were degraded and integrated into the newly forming bone. $\underline{.3}$

\section{Hydroxyapatite/polyamide}

HA may not have adequate properties to mimic the composition, structure, and properties of natural bone. $\frac{85}{\text { Incorporation of polyamide }}$ presents improved mechanical properties, since it is similar to the chemical structure of bone collagen and shows outstanding mechanical properties. $\underline{86}$

In a previous study, a nanocomposite of $\mathrm{HA}$ and polyamide and CAD/CAM was used in the treatment of maxillofacial defects. $\frac{85}{}$ Using $C T$ and $A M$, a perfect-fitting condylar implant from biomimetic nano $\mathrm{HA}$ /polyamide scaffold was fabricated for a patient who suffered from mandibular angle reduction with malocclusion, deviated mouth, collapse of the right side of the face, and masticatory problems. The patient finally recovered good jaw contour, appearance, and TMJ function. The report recommended that CAD/CAM and RP nano $\mathrm{HA}$ /polyamide implants may be a practical option compared to the gold standard autografts for maxillofacial defects. $\frac{85}{}$

\section{Cell-hydrogel}

AM techniques in cell-based tissue engineering have resulted in the development of a new model, called organ or tissue printing, wherein hydrogel matrices and cells are spatially arranged into layered hybrid structures, with organized architecture and defined cellular placement. $\underline{87}$ Development of cell-seeded implants that mimic native tissues considering anatomical specific shape, spatial configuration, and the cell's environment may finally speed up and enhance the

Journal of Prosthodontics, Vol 25, No. 4 (June 2016): pg. 310-318. DOI. This article is @ Wiley and permission has been granted for this version to appear in e-Publications@Marquette. Wiley does not grant permission for this article to be further copied/distributed or hosted elsewhere without the express permission from Wiley. 
functionality of tissue-engineered scaffolds. $\frac{87}{}$ Fedorovich et al characterized layered 3D fiber deposition of osteoprogenitor cells in hydrogels to use the concept of organ or tissue printing for making vascularized bone grafts. $\frac{87}{}$ For this purpose, a Bioplotter pneumatic dispensing system was employed for fiber deposition, and the cellhydrogel composites were placed into a syringe and loaded into the bioplotter to produce four-layer constructs. The results showed that embedded cells were homogeneously dispersed inside the deposited hydrogel scaffolds, and the cells remained intact after the deposition. $\underline{87}$

Although the results of other research groups reported decreased cell viability at similar deposition pressures of printing process, the results of this study confirmed that the printing process does not negatively influence the viability of cells. $\frac{88}{}$ This suggests that the 3D fiber deposition approach can be used for bone tissue printing and indicates potential for the development of vascularized bone grafts. $\frac{87}{}$

\section{Other composites}

The main benefits of low-temperature 3D printing is its capability to construct polymer/mineral composites with increased beneficial material properties to include growth factors and drugs to enhance bone regeneration or combat infection. $\underline{89}$ Fused deposition modeling has frequently used biomedical polymers with low melting temperatures. $\underline{90}$ Materials employed in fused deposition modeling to produce porous scaffolds are polycaprolactone-bioactive glass (PCL$\mathrm{BaG}), \underline{91} \mathrm{~L}$-lactide/e-caprolactone, $\underline{91}$ polylactide-co-glycolide acid (PLGA) with collagen infiltration, $\underline{92}$ polycaprolactone-tricalcium phosphate (PCL-TCP) with gentamicin, $\underline{93}$ PCL-TCP, $\underline{94}$ PLGA-TCP coated with HA, $\underline{95}$ PCLPLGA-TCP, $\underline{96}$ PLGA-PCL, $\underline{97}$ and PCL coated with gelatin. $\underline{98}$ The mentioned composite materials have potential to be used in applications like cartilage and bone tissue engineering, $\underline{99}$ antibiotic delivery systems, $\underline{93}$ and for treatment of osseous craniofacial defects in humans. $\frac{94}{}$ A polymer (polypropylene)/ceramic (TCP) composite scaffold with controlled porosity and various interior architectures has been generated via the fused deposition modeling method. In vitro test results indicated that these experimental scaffolds were non-toxic and had good cell growth characteristics. $\underline{100}$

Journal of Prosthodontics, Vol 25, No. 4 (June 2016): pg. 310-318. DOI. This article is (C) Wiley and permission has been granted for this version to appear in e-Publications@Marquette. Wiley does not grant permission for this article to be further copied/distributed or hosted elsewhere without the express permission from Wiley. 
Sherwood et al have also produced osteochondral hybrid composites in which the upper area was D, L-PLGA/L-PLA with 90\% porosity for cartilage regeneration, and the lower area was LPLGA/TCP to enhance bone healing. The scaffold was developed employing the combination of 3D printing and particulate leaching techniques. $\frac{101}{1}$ Other compositions including PCL/TCP or PCL/HA have been used with fused deposition modeling because of their mechanical and biological characteristics for bone healing. $\underline{102}$

As another technique in 3D printing, selective laser sintering has been known as a method feasible with medical data to make anatomyspecific constructions. $\underline{90}$ In one study, polyvinyl alcohol/hydroxyapatite (PVA/HA) composite was produced via the selective laser sintering method, whereas HA particles were covered with PVA by the use of spray-drying or physical blending. This material was introduced for joints and craniofacial applications. $\underline{103} \mathrm{~A}$ mandibular condyle scaffold was fabricated using this technology by means of CT data from a pig condyle. $\underline{104}$ The combination of simulations and selective laser sintering method facilitates the capability to formulate scaffolds with anatomically shaped exterior architectures and porous internal construction. The usual materials employed in selective laser sintering are HA and PCL, $\underline{105} \beta$-TCP and PCL with collagen coating, $\underline{106}$ Poly(3hydroxybutyrate-co-3-hydroxyvalerate)/Ca-P (PHBV/Ca-P), and polyL-lactide acid/calcium hydroxyapatite (PLLA/CHAp). $\underline{107,108}$

\section{Metals}

\section{Titanium}

The amount of load sharing between the bone and implant depends on the elastic modulus of the implant. 109 Therefore, it is important that the implant has similar mechanical behavior, especially elastic modulus, to that of the natural bone. 109 Potential biomaterials for bone graft scaffolds, ceramics, and polymers have been widely investigated; however, at times, they are not able to provide the necessary mechanical requirements under the given loads. $\underline{110,111}$

As a metallic biomaterial, titanium (Ti) has been extensively employed in recent investigations due to its high corrosion resistance, high strength/weight ratio, and confirmed biocompatibility. $\frac{110,112}{}$ Ti has

Journal of Prosthodontics, Vol 25, No. 4 (June 2016): pg. 310-318. DOI. This article is @ Wiley and permission has been granted for this version to appear in e-Publications@Marquette. Wiley does not grant permission for this article to be further copied/distributed or hosted elsewhere without the express permission from Wiley. 
low density and suitable mechanical properties such as elastic modulus, fatigue strength, and toughness. $\frac{113}{1 t}$ It has been extensively employed for construction of implants, such as prosthetic joints, trauma-locking plating systems, dental implants, screws, membranes, and heart valves. $\frac{109}{}$ Although the elastic modulus of bulk Ti is more than that of natural bone, it is still less than other bio-metals such as stainless steel or cobalt alloy. $\frac{109}{}$ Table 1 summarizes the strength and modulus of the natural jaw bone and several other bulk biomaterials usually utilized as implants. 109

Table 1. The strength and modulus of the natural jawbone and several bulk biomaterials usually used as the implants. Adopted from work by Wiria et al. $\underline{109}$

\begin{tabular}{lll}
\multicolumn{1}{c}{ Material } & \multicolumn{1}{c}{$\begin{array}{c}\text { Strength (MPa) } \\
\text { Natural jaw bone }\end{array}$} & \multicolumn{1}{c}{$\begin{array}{c}\text { Modulus } \\
3 \text { to } 20\end{array}$} \\
PLGA & 2.82 & 2 \\
Stainless steel 316L & 170 to 750 & 200 \\
Co-Cr-Mo & 275 to 1585 & 200 to 230 \\
Ti-6Al-4V & 895 to 930 & 110 to 114 \\
Commercially pure titanium & 240 to 550 & 102 to 105 \\
Alumina & 400 & 350 \\
Yttria-stabilized zirconia & 900 to 1400 & 210
\end{tabular}

Several biomaterials have a strength and modulus greater than bone (Table 1). ${ }^{109}$ It appears that pure Ti has a high potential to be engineered so its modulus is close to that of bone. 109 By introducing porosity to bulk Ti to produce Ti scaffolds through engineering approaches, its mechanical properties could be manipulated. Moreover, the porosity provides the routes for the cells to grow inside the porous implant. $\frac{114}{1}$ However, none of the conventional methods have allowed for making porous materials with a desirable shape and interconnected pores. To overcome the problems associated with conventional methods, AM technology has been utilized.115 Until recently, AM has mostly focused on polymer and ceramic

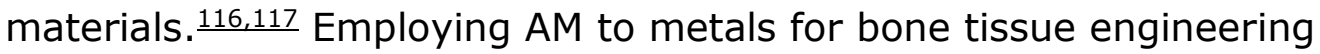
has posed considerable challenges. $\underline{113}$

Ryan et al 110 used a commercial 3D printer (Thermojet) to produce a porous Ti scaffold by a sacrificial wax template. Powder metallurgy was employed to create porous Ti by filling the Ti slurry around the wax template. The results of this research indicated that

Journal of Prosthodontics, Vol 25, No. 4 (June 2016): pg. 310-318. DOI. This article is @ Wiley and permission has been granted for this version to appear in e-Publications@Marquette. Wiley does not grant permission for this article to be further copied/distributed or hosted elsewhere without the express permission from Wiley. 
the porous $\mathrm{Ti}$ scaffolds with porosities of around $66.8 \%$ had compression strength of 104.4 and $23.5 \mathrm{MPa}$ in axial and transverse directions, respectively, showing Ti's anisotropic properties. Cultured osteoblast cells have also retained their metabolic activity on the surface of Ti materials. 110

Wiria et al $\underline{109}$ also produced a porous $\mathrm{Ti}$ implant using 3D printing with an elastic modulus of around 4.8 to $13.2 \mathrm{GPa}$ and compressive strength of 167 to $455 \mathrm{MPa}$. The elastic modulus of fabricated porous Ti scaffolds was in the range of natural bone. The cytocompatibility tests in this study showed that the produced $\mathrm{Ti}$ scaffolds could provide a suitable surface for cells to live, proliferate, and grow. $\underline{109} \mathrm{Ti}$ alloy (Ti6Al4V) was also used to produce scaffolds with apt amounts of porosity, pore size, and interconnected pores. Li et al $\underline{113}$ developed 3D fiber deposition as an AM technique. The experimental result of this study illustrated how the parameters control the construction of porous scaffolds. $\frac{113}{12}$ In summary, $\mathrm{Ti}$ and $\mathrm{Ti}$ alloy implants produced by 3D printing and tested by biomechanical and in vitro investigations exhibit good mechanical properties and biocompatibility, which confirm their potential use in tissue engineering. $\underline{109}$

\section{Conclusion}

Due to bone resorption, congenital defects, craniofacial defects, trauma, and pathologies, lost tissue is often a difficult-to-treat issue. During prosthodontic and dentoalveolar defect rehabilitation, it is imperative that anatomical uniformity is maintained but also that appearance and tissue function is reestablished. $\underline{118}$ The gold standard for management of such defects is autogenous grafts; however, implanted scaffolds of varying materials have become a substitute. For an ideal bioscaffold, certain characteristics need to be met, including the provision of a 3D structure for the regeneration of natural tissues and the ability to degrade in a steady manner and be replaced completely by natural tissue. $\frac{119}{}$ Such 3D scaffolds are customized and manufactured using additive manufacturing methods. Several different materials and their advantages and disadvantages (Tables $\underline{2}$ and $\underline{3}$ ) have been investigated, including composites and metals as described in this review. Currently one of the many challenges faced is to build a

Journal of Prosthodontics, Vol 25, No. 4 (June 2016): pg. 310-318. DOI. This article is @ Wiley and permission has been granted for this version to appear in e-Publications@Marquette. Wiley does not grant permission for this article to be further copied/distributed or hosted elsewhere without the express permission from Wiley. 
NOT THE PUBLISHED VERSION; this is the author's final, peer-reviewed manuscript. The published version may be accessed by following the link in the citation at the bottom of the page.

scaffold with optimal properties, while minimizing cost, toxicity, and discomfort.

Table 2. Summary of bioceramic materials: advantages, disadvantages, and potential materials used to construct composites

\begin{tabular}{|c|c|c|c|}
\hline Bioceramics & Tri-calcium phosphate & Hydroxyapatite & Bioglass \\
\hline Advantages & $\begin{array}{l}\text {-Molding capability into } \\
\text { defects in granule form } \\
\text {-Osteoconductive }\end{array}$ & $\begin{array}{l}\text {-Biocompatible } \\
\text {-Osteoconductive } \\
\text {-Non-immunogenic }\end{array}$ & $\begin{array}{l}\text {-Ability to support } \\
\text { osteoblast cells } \\
\text {-Bonding to soft and } \\
\text { hard tissues }\end{array}$ \\
\hline & & -Mechanically stable & $\begin{array}{l}\text {-Angiogenesis } \\
\text { stimulation with VEGF }\end{array}$ \\
\hline Disadvantages & $\begin{array}{l}\text {-Lack of macroporosity } \\
\text {-Must maintain low } \\
\text { sintering temperature }\end{array}$ & $\begin{array}{l}\text {-Expensive } \\
\text {-Does not optimally } \\
\text { interact with liquid binder }\end{array}$ & $\begin{array}{l}\text {-Cytotoxicity with } \\
\text { surrounding } \\
\text { environment }\end{array}$ \\
\hline $\begin{array}{l}\text { Potential } \\
\text { materials for } \\
\text { making } \\
\text { composite }\end{array}$ & $\begin{array}{l}\text {-Collagen } \\
\text {-Hydroxyapatite }\end{array}$ & $\begin{array}{l}\text {-Polyamide } \\
\text {-Chitosan }\end{array}$ & $\begin{array}{l}\text {-Polyethylene } \\
\text {-Poly (a-hydroxy acid) }\end{array}$ \\
\hline
\end{tabular}

Table 3. Summary of biopolymer materials: advantages, disadvantages, and potential materials used to construct composite

Biopolymers

Advantages

Disadvantages

-Mechanically

-Rapid degradability

Potential materials for

making composite vulnerable

Alginate

-Inducing chondrocyte proliferation

-Chitosan

-Polylactide

\section{Biogenic} polyphosphate

-Osteocytes stimulation to undergo an anabolic process

-Regulator of scaffold porosity

-Osteoconductive

-Yet to be studied

-Calcium
-Not apparent osteoblast differentiation

-Alginate

Biogenic silica

-Biocompatible

-Bioactive

-Stimulator of

-Collagen

\section{References}

${ }^{1} \mathrm{Hull}$ CW: Apparatus for production of three-dimensional objects by stereolithography. Google Patents, 1986

${ }^{2}$ Murphy SV, Atala A: 3D bioprinting of tissues and organs. Nat Biotechnol $2014 ; 32: 773-785$

Journal of Prosthodontics, Vol 25, No. 4 (June 2016): pg. 310-318. DOI. This article is @ Wiley and permission has been granted for this version to appear in e-Publications@Marquette. Wiley does not grant permission for this article to be further copied/distributed or hosted elsewhere without the express permission from Wiley. 
NOT THE PUBLISHED VERSION; this is the author's final, peer-reviewed manuscript. The published version may be accessed by following the link in the citation at the bottom of the page.

${ }^{3}$ Zopf DA, Hollister SJ, Nelson ME, et al: Bioresorbable airway splint created with a three-dimensional printer. New Engl J Med 2013;368:20432045

${ }^{4}$ Nakamura M, Iwanaga S, Henmi C, et al: Biomatrices and biomaterials for future developments of bioprinting and biofabrication. Biofabrication 2010;2:014110

${ }^{5}$ Campbell T, Williams C, Ivanova O, et al: Could 3D Printing Change the World? Technologies, Potential, and Implications of Additive Manufacturing. Washginton, DC, Atlantic Council, 2011. Available online at http://www.atlanticcouncil.org/publications/reports/could-3dprinting-change-the-world. Accessed August 24, 2015

${ }^{6}$ Peltola SM, Melchels FP, Grijpma DW, et al: A review of rapid prototyping techniques for tissue engineering purposes. Ann Med 2008;40:268280

${ }^{7}$ Murphy SV, Skardal A, Atala A: Evaluation of hydrogels for bio-printing applications. J Biomed Mater Res A 2013;101:272-284

${ }^{8}$ Vorndran $E$, Klarner M, Klammert $U$, et al: 3D powder printing of $\beta$-tricalcium phosphate ceramics using different strategies. Adv Eng Mater 2008;10:B67-B71

${ }^{9}$ Herring S, Ochareon P: Bone-special problems of the craniofacial region. Orthod Craniofac Res 2005;8:174-182

${ }^{10}$ Tessier $\mathrm{P}$, Kawamoto $\mathrm{H}$, Matthews $\mathrm{D}$, et al: Autogenous bone grafts and bone substitutes-tools and techniques: I. A 20,000-case experience in maxillofacial and craniofacial surgery. Plast Reconstr Surg 2005; $116: 6 S-24 S$

${ }^{11}$ Cheng XG, Yoo JJ, Hale RG, et al: 3D printed biomaterials for maxillofacial tissue engineering and reconstruction-a review. Open J Biomed Mater Res 2014;1:1-7

${ }^{12}$ Eppley BL, Pietrzak WS, Blanton MW: Allograft and alloplastic bone substitutes: a review of science and technology for the craniomaxillofacial surgeon. J Craniofac Surg 2005;16:981-989

${ }^{13}$ Hallman M, Thor A: Bone substitutes and growth factors as an alternative/complement to autogenous bone for grafting in implant dentistry. Periodontol 2000 2008;47:172-192

${ }^{14}$ Fischer-Brandies E, Dielert E: Clinical use of tricalciumphosphate and hydroxyapatite in maxillofacial surgery. J Oral Implantol 1984;12:4044

${ }^{15}$ Cheng $X$, Davis $M$, Hale $R$, et al: 3D Printed biomaterials for maxillofacial tissue engineering and reconstruction-a review. Open $\mathrm{J}$ Biomed Mater Res 2014;1:1-7

${ }^{16}$ Hutmacher DW: Scaffolds in tissue engineering bone and cartilage. Biomaterials 2000;21:2529-2543

Journal of Prosthodontics, Vol 25, No. 4 (June 2016): pg. 310-318. DOI. This article is @ Wiley and permission has been granted for this version to appear in e-Publications@Marquette. Wiley does not grant permission for this article to be further copied/distributed or hosted elsewhere without the express permission from Wiley. 
NOT THE PUBLISHED VERSION; this is the author's final, peer-reviewed manuscript. The published version may be accessed by following the link in the citation at the bottom of the page.

${ }^{17}$ Freyman T, Yannas I, Gibson L: Cellular materials as porous scaffolds for tissue engineering. Prog Mater Sci 2001;46:273-282

${ }^{18}$ Karageorgiou V, Kaplan D: Porosity of 3D biomaterial scaffolds and osteogenesis. Biomaterials 2005;26:5474-5491

${ }^{19}$ Wang MO, Vorwald CE, Dreher ML, et al: Evaluating 3D-printed biomaterials as scaffolds for vascularized bone tissue engineering. Adv Mater 2015;27:138-144

${ }^{20}$ Hench L: Bioceramics: from concept to clinic. Am Ceram Soc Bull $1993 ; 72: 93-98$

${ }^{21}$ Carrodeguas R, De Aza S: a-Tricalcium phosphate: synthesis, properties and biomedical applications. Acta Biomater 2011;7:3536-3546

${ }^{22}$ Ando J: Tricalcium phosphate and its variation. Bull Chem Soc Jpn $1958 ; 31: 196-201$

${ }^{23}$ Nancollas $\mathrm{GH}$, Zhang J: Formation and dissolution mechanisms of calcium phosphates in aqueous systems. In Brown PW, Constanz B (eds): Hydroxyapatite and Related Materials. Boca Raton, FL, CRC Press, 1994, pp 73-81

${ }^{24}$ Lacefield WR: Hydroxyapatite coatings. Adv Ser Ceram 1993;1:223-238

${ }^{25}$ Klein C, Wolke J, De Groot K: Stability of calcium phosphate ceramics and plasma sprayed coating. Adv Ser Ceram 1993;1:199-222

${ }^{26}$ Gbureck U, Hölzel T, Klammert U, et al: Resorbable dicalcium phosphate bone substitutes prepared by 3D powder printing. Adv Function Mater 2007; 17:3940-3945

${ }^{27} \mathrm{RyuH}-\mathrm{S}$, YounH-J, Hong KS, et al: An improvement in sintering property of $\beta$-tricalcium phosphate by addition of calcium pyrophosphate.

Biomaterials 2002;23:909-914

${ }^{28}$ Miranda $P$, Saiz E, Gryn K, et al: Sintering and robocasting of $\beta$-tricalcium phosphate scaffolds for orthopaedic applications. Acta Biomater 2006;2:457-466

${ }^{29}$ Damien CJ, Parsons JR: Bone graft and bone graft substitutes: a review of current technology and applications. J App/ Biomater 1991;2:187-208

${ }^{30}$ Oonishi $\mathrm{H}$ : Orthopaedic applications of hydroxyapatite. Biomaterials 1991;12:171-178

${ }^{31}$ Roy DM, Linnehan SK: Hydroxyapatite formed from coral skeletal carbonate by hydrothermal exchange. Nature 1974;247:220-222

${ }^{32}$ Fabbri M, Celotti G, Ravaglioli A: Hydroxyapatite-based porous aggregates: physico-chemical nature, structure, texture and architecture. Biomaterials 1995;16:225-228.

${ }^{33}$ Werner J, Linner-Krčmar B, Friess W, et al: Mechanical properties and in vitro cell compatibility of hydroxyapatite ceramics with graded pore structure. Biomaterials 2002;23:4285-4294

Journal of Prosthodontics, Vol 25, No. 4 (June 2016): pg. 310-318. DOI. This article is @ Wiley and permission has been granted for this version to appear in e-Publications@Marquette. Wiley does not grant permission for this article to be further copied/distributed or hosted elsewhere without the express permission from Wiley. 
NOT THE PUBLISHED VERSION; this is the author's final, peer-reviewed manuscript. The published version may be accessed by following the link in the citation at the bottom of the page.

${ }^{34}$ Langton $C$, Whitehead M, Langton $D$, et al: Development of a cancellous bone structural model by stereolithography for ultrasound characterisation of the calcaneus. Med Eng Physics 1997;19:599-604

${ }^{35}$ Cesarano J, Segalman R, Calvert P: Robocasting provides moldless fabrication from slurry deposition. Ceram Industry 1998;148:94

${ }^{36}$ Smay JE, Cesarano J, Lewis JA: Colloidal inks for directed assembly of 3-D periodic structures. Langmuir 2002;18:5429-5437

${ }^{37}$ Michna S, Wu W, Lewis JA: Concentrated hydroxyapatite inks for directwrite assembly of 3-D periodic scaffolds. Biomaterials 2005;26:56325639

${ }^{38}$ Chumnanklang R, Panyathanmaporn T, Sitthiseripratip K, et al: 3D printing of hydroxyapatite: effect of binder concentration in pre-coated particle on part strength. Mater Sci Eng C 2007;27:914-921

${ }^{39}$ Leukers B, Gülkan H, Irsen SH, et al: Hydroxyapatite scaffolds for bone tissue engineering made by 3D printing. J Mater Sci Mater Med 2005; 16:1121-1124

${ }^{40}$ Irsen SH, Leukers B, Höckling C, et al: Bioceramic granulates for use in 3D printing: process engineering aspects. Materialwissenschaft Werkstofftechnik 2006;37:533-537

${ }^{41}$ Hench LL, Wilson J: Surface-active biomaterials. Science 1984;226:630-636

${ }^{42}$ Wheeler $D$, Stokes $K$, Park $H$, et al: Evaluation of particulate Bioglass $₫$ in a rabbit radius ostectomy model. J Biomed Mater Res 1997;35:249-254

${ }^{43}$ Leach JK, Kaigler D, Wang Z, et al: Coating of VEGF-releasing scaffolds with bioactive glass for angiogenesis and bone regeneration. Biomaterials 2006;27:3249-3255

${ }^{44}$ Rainer A, Giannitelli SM, Abbruzzese F, et al: Fabrication of bioactive glassceramic foams mimicking human bone portions for regenerative medicine. Acta Biomater 2008;4:362-369

${ }^{45} \mathrm{Kokubo} \mathrm{T}$, Takadama $\mathrm{H}$ : How useful is SBF in predicting in vivo bone bioactivity? Biomaterials 2006;27:2907-2915

${ }^{46}$ Ratner BD, Hoffman AS, Schoen FJ, et al: Biomaterials Science: An Introduction to Materials in Medicine. San Diego, Academic Press, 2006.

${ }^{47}$ Hench LL: Biomaterials: a forecast for the future. Biomaterials 1998; 19:1419-1423

48 Jones JR, Tsigkou O, Coates EE, et al: Extracellular matrix formation and mineralization on a phosphate-free porous bioactive glass scaffold using primary human osteoblast (HOB) cells. Biomaterials 2007;28:1653-1663

${ }^{49} \mathrm{Kim} \mathrm{K}$, Yeatts A, Dean D, et al: Stereolithographic bone scaffold design parameters: osteogenic differentiation and signal expression. Tissue Eng Part B Rev 2010;16:523-539

Journal of Prosthodontics, Vol 25, No. 4 (June 2016): pg. 310-318. DOI. This article is @ Wiley and permission has been granted for this version to appear in e-Publications@Marquette. Wiley does not grant permission for this article to be further copied/distributed or hosted elsewhere without the express permission from Wiley. 
NOT THE PUBLISHED VERSION; this is the author's final, peer-reviewed manuscript. The published version may be accessed by following the link in the citation at the bottom of the page.

${ }^{50}$ Obregon $\mathrm{F}$, Vaquette C, Ivanovski S, et al: Three-dimensional bioprinting for regenerative dentistry and craniofacial tissue engineering. J Dent Res 2015;94:143S-152S

${ }^{51}$ Marijnissen WJ, van Osch GJ, Aigner J, et al: Alginate as a chondrocytedelivery substance in combination with a non-woven scaffold for cartilage tissue engineering. Biomaterials 2002;23:1511-1517

${ }^{52} \mathrm{Li} \mathrm{Z}$, Zhang $\mathrm{M}$ : Chitosan-alginate as scaffolding material for cartilage tissue engineering. J Biomed Mater Res Part A 2005;75:485-493

${ }^{53}$ Gharravi AM, Orazizadeh M, Ansari-Asl K, et al: Design and fabrication of anatomical bioreactor systems containing alginate scaffolds for cartilage tissue engineering. Avicenna J Med Biotechnol 2012;4:65-74

${ }^{54} \mathrm{Almarza} \mathrm{AJ}$, Athanasiou KA: Seeding techniques and scaffolding choice for tissue engineering of the temporomandibular joint disk. Tissue Eng 2004; 10:1787-1795

${ }^{55}$ Fragonas $\mathrm{E}$, Valente $\mathrm{M}$, Pozzi-Mucelli $\mathrm{M}$, et al: Articular cartilage repair in rabbits by using suspensions of allogenic chondrocytes in alginate. Biomaterials 2000;21:795-801

${ }^{56}$ Lee KY, Mooney DJ: Hydrogels for tissue engineering. Chem Rev 2001;101:1869-1879

${ }^{57}$ Paige KT, Cima LG, Yaremchuk MJ, et al: Injectable cartilage. Plast Reconstr Surg 1995;96:1390-1398; discussion 1399-1400

${ }^{58}$ Sims CD, Butler PE, Casanova $R$, et al: Injectable cartilage using polyethylene oxide polymer substrates. Plast Reconstr Surg 1996;98:843-850

${ }^{59}$ Drury JL, Mooney DJ: Hydrogels for tissue engineering: scaffold design variables and applications. Biomaterials 2003;24:4337-4351

${ }^{60}$ Park $\mathrm{H}$, Lee $\mathrm{KY}$ : Cartilage regeneration using biodegradable oxidized alginate/hyaluronate hydrogels. J Biomed Mater Res $A$ 2014;102:4519-4525

${ }^{61}$ Xavier JR, Thakur T, Desai P, et al: Bioactive nanoengineered hydrogels for bone tissue engineering: a growth-factor-free approach. ACS Nano 2015;9:3109-3118

${ }^{62}$ Fielding GA, Bandyopadhyay A, Bose S: Effects of silica and zinc oxide doping on mechanical and biological properties of 3D printed tricalcium phosphate tissue engineering scaffolds. Dent Mater 2012;28:113-122

${ }^{63}$ Fielding GA, Bandyopadhyay A, Bose S: Effects of silica and zinc oxide doping on mechanical and biological properties of 3D printed tricalcium phosphate tissue engineering scaffolds. Dent Mater 2012;28:113-122

${ }^{64}$ Wang $X$, Schroder HC, Feng Q, et al: The deep-sea natural products, biogenic polyphosphate (Bio-PolyP) and biogenic silica (Bio-Silica), as biomimetic scaffolds for bone tissue engineering: fabrication of a morphogenetically-active polymer. Marine Drugs 2013;11:718-746

Journal of Prosthodontics, Vol 25, No. 4 (June 2016): pg. 310-318. DOI. This article is @ Wiley and permission has been granted for this version to appear in e-Publications@Marquette. Wiley does not grant permission for this article to be further copied/distributed or hosted elsewhere without the express permission from Wiley. 
NOT THE PUBLISHED VERSION; this is the author's final, peer-reviewed manuscript. The published version may be accessed by following the link in the citation at the bottom of the page.

${ }^{65}$ Wang X, Schroder HC, Muller WE: Enzyme-based biosilica and biocalcite: biomaterials for the future in regenerative medicine. Trends Biotechnol 2014;32:441-447

${ }^{66}$ Wang X, Schroder HC, Wiens M, et al: Bio-silica and bio-polyphosphate: applications in biomedicine (bone formation). Curr Opin Biotechnol 2012;23: 570-578

${ }^{67}$ Grynpas MD, Pilliar RM, Kandel RA, et al: Porous calcium polyphosphate scaffolds for bone substitute applications in vivo studies. Biomaterials 2002; 23:2063-2070

${ }^{68}$ Pilliar RM, Filiaggi MJ, Wells JD, et al: Porous calcium polyphosphate scaffolds for bone substitute applications-in vitro characterization. Biomaterials 2001;22:963-972

${ }^{69}$ Wang X, Schroder HC, Schlossmacher U, et al: Inorganic polyphosphates: biologically active biopolymers for biomedical applications. Prog Mol Subcell Biol 2013;54:261-294

${ }^{70}$ Wang MO, Vorwald CE, Dreher ML, et al: Evaluating 3D-printed biomaterials as scaffolds for vascularized bone tissue engineering. Adv Mater 2015;27:138-144

${ }^{71}$ Muller WE, Schroder HC, Shen Z, et al: Inorganic polymers: morphogenic inorganic biopolymers for rapid prototyping chain. Prog Mol Subcell Biol 2013;54:235-259

${ }^{72}$ Schroder HC, Wang $X$, Schlossmacher $U$, et al: Biogenic inorganic polysilicates (biosilica): formation and biomedical applications. Prog Mol Subcell Biol 2013;54:197-234

${ }^{73}$ Plazas Bonilla CE, Trujillo S, Demirdogen B, et al: New porous polycaprolactone-silica composites for bone regeneration. Mater $\mathrm{Sci}$ Eng C Mater Biol Appl 2014;40:418-426

${ }^{74}$ Henstock JR, Canham LT, Anderson SI: Silicon: the evolution of its use in biomaterials. Acta Biomater 2015;11:17-26

${ }^{75}$ Wang S, Wang X, Draenert FG, et al: Bioactive and biodegradable silica biomaterial for bone regeneration. Bone 2014;67:292-304

${ }^{76}$ Madhumathi K, Sudheesh Kumar PT, Kavya KC, et al: Novel chitin/nanosilica composite scaffolds for bone tissue engineering applications. Int J Biol Macromol 2009;45:289-292

${ }^{77}$ BainoF, Vitale-Brovarone C: Three-dimensional glass-derived scaffolds for bone tissue engineering: current trends and forecasts for the future. $J$ Biomed Mater Res A 2011;97:514-535

${ }^{78}$ Vallet-Regi M: Nanostructured mesoporous silica matrices in nanomedicine. J Intern Med 2010;267:22-43

${ }^{79}$ Wan AC, Ying JY: Nanomaterials for in situ cell delivery and tissue regeneration. Adv Drug Deliv Rev 2010;62:731-740

Journal of Prosthodontics, Vol 25, No. 4 (June 2016): pg. 310-318. DOI. This article is @ Wiley and permission has been granted for this version to appear in e-Publications@Marquette. Wiley does not grant permission for this article to be further copied/distributed or hosted elsewhere without the express permission from Wiley. 
NOT THE PUBLISHED VERSION; this is the author's final, peer-reviewed manuscript. The published version may be accessed by following the link in the citation at the bottom of the page.

${ }^{80}$ Yun HS, Kim SE, Hyun YT, et al: Hierarchically mesoporous-macroporous bioactive glasses scaffolds for bone tissue regeneration. $J$ Biomed Mater Res B Appl Biomater 2008;87:374-380

${ }^{81}$ Vallet-Regi M, Balas F: Silica materials for medical applications. Open Biomed Eng J 2008;2:1-9

${ }^{82}$ Liu X, Ma PX: Polymeric scaffolds for bone tissue engineering. Ann Biomed Eng 2004;32:477-486

${ }^{83}$ Inzana JA, Olvera D, Fuller SM, et al: 3D printing of composite calcium phosphate and collagen scaffolds for bone regeneration. Biomaterials 2014;35:4026-4034

${ }^{84} \mathrm{Xu} \mathrm{T}$, Binder KW, Albanna MZ, et al: Hybrid printing of mechanically and biologically improved constructs for cartilage tissue engineering applications. Biofabrication 2013;5:015001

${ }^{85} \mathrm{Li} \mathrm{J}$, Hsu Y, Luo E, et al: Computer-aided design and manufacturing and rapid prototyped nanoscale hydroxyapatite/polyamide (n-HA/PA) construction for condylar defect caused by mandibular angle ostectomy. Aesthet Plast Surg 2011;35:636-640

${ }^{86}$ Wang $\mathrm{H}$, Li Y, Zuo $\mathrm{Y}$, et al: Biocompatibility and osteogenesis of biomimetic nano-hydroxyapatite/polyamide composite scaffolds for bone tissue engineering. Biomaterials 2007;28:3338-3348

${ }^{87}$ Fedorovich NE, De Wijn JR, Verbout AJ, et al: Three-dimensional fiber deposition of cell-laden, viable, patterned constructs for bone tissue printing. Tissue Eng Part A 2008;14:127-133

${ }^{88}$ Smith CM, Christian JJ, Warren WL, et al: Characterizing environmental factors that impact the viability of tissue-engineered constructs fabricated by a direct-write bioassembly tool. Tissue Eng 2007; 13:373-383

${ }^{89}$ Vorndran $E$, Klammert $U$, Ewald $A$, et al: Simultaneous immobilization of bioactives during 3D powder printing of bioceramic drug-release matrices. Adv Funct Mater 2010;20:1585-1591

${ }^{90}$ Chia HN, Wu BM: Recent advances in 3D printing of biomaterials. J Biol Eng 2015;103:1415-1423

${ }^{91}$ Korpela J, Kokkari A, Korhonen $\mathrm{H}$, et al: Biodegradable and bioactive porous scaffold structures prepared using fused deposition modeling. J Biomed Mater Res B Appl Biomater 2013;101:610-619

${ }^{92}$ Yen $\mathrm{HJ}$, Tseng CS, Hsu SH, et al: Evaluation of chondrocyte growth in the highly porous scaffolds made by fused deposition manufacturing (FDM) filled with type II collagen. Biomed Microdevices 2009;11:615-624

${ }^{93}$ Teo EY, OngS-Y, Chong MSK, et al: Polycaprolactone-based fused deposition modeled mesh for delivery of antibacterial agents to infected wounds. Biomaterials 2011;32:279-287

Journal of Prosthodontics, Vol 25, No. 4 (June 2016): pg. 310-318. DOI. This article is @ Wiley and permission has been granted for this version to appear in e-Publications@Marquette. Wiley does not grant permission for this article to be further copied/distributed or hosted elsewhere without the express permission from Wiley. 
NOT THE PUBLISHED VERSION; this is the author's final, peer-reviewed manuscript. The published version may be accessed by following the link in the citation at the bottom of the page.

${ }^{94}$ Probst F, Hutmacher D, Müller D, et al: Calvarial reconstruction by customized bioactive implant. Handchir Mikrochir Plast Chir 2010;42:369-373

${ }^{95} \mathrm{Kim} \mathrm{J}, \mathrm{McBride} \mathrm{S}$, Tellis B, et al: Rapid-prototyped PLGA/ $\beta$ TCP/hydroxyapatite nanocomposite scaffolds in a rabbit femoral defect model. Biofabrication 2012;4:025003

${ }^{96}$ ShimJ-H, MoonT-S, Yun MJ, et al: Stimulation of healing within a rabbit calvarial defect by a PCL/PLGA scaffold blended with TCP using solid freeform fabrication technology. J Mater Sci Mater Med 2012;23:29933002

${ }^{97}$ KimJY, Cho D-W: Blended PCL/PLGA scaffold fabrication using multi-head deposition system. Microelectron Eng 2009;86:1447-1450

${ }^{98}$ Van Bael S, Desmet T, Chai YC, et al: In vitro cell-biological performance and structural characterization of selective laser sintered and plasma surface functionalized polycaprolactone scaffolds for bone regeneration. Mater Sci Eng C 2013;33:3404-3412

${ }^{99} \mathrm{Kim}$ SS, Utsunomiya $\mathrm{H}$, Koski JA, et al: Survival and function of hepatocytes on a novel three-dimensional synthetic biodegradable polymer scaffold with an intrinsic network of channels. Ann Surg 1998;228:8-13

${ }^{100}$ Kalita SJ, Bose S, Hosick HL, et al: Development of controlled porosity polymer-ceramic composite scaffolds via fused deposition modeling. Mater Sci Eng C 2003;23:611-620

${ }^{101}$ Sherwood JK, Riley SL, Palazzolo R, et al: A three-dimensional osteochondral composite scaffold for articular cartilage repair. Biomaterials 2002;23:4739-4751

${ }^{102}$ Rai B, TeohS-H, Ho K, et al: The effect of rhBMP-2 on canine osteoblasts seeded onto 3D bioactive polycaprolactone scaffolds. Biomaterials 2004;25:5499-5506

${ }^{103}$ Chua C, Leong K, Tan K, et al: Development of tissue scaffolds using selective laser sintering of polyvinyl alcohol/hydroxyapatite biocomposite for craniofacial and joint defects. J Mater Sci Mater Med 2004; 15:1113-1121

${ }^{104}$ Williams JM, Adewunmi A, Schek RM, et al: Bone tissue engineering using polycaprolactone scaffolds fabricated via selective laser sintering. Biomaterials 2005;26:4817-4827

${ }^{105}$ Eosoly S, Brabazon D, Lohfeld S, et al: Selective laser sintering of hydroxyapatite/poly- $\varepsilon$-caprolactone scaffolds. Acta Biomater 2010;6:2511-2517

${ }^{106}$ Liao HT, Lee MY, Tsai WW, et al.: Osteogenesis of adipose-derived stem cells on polycaprolactone- $\beta$-tricalcium phosphate scaffold fabricated via selective laser sintering and surface coating with collagen type I. J Tissue Eng Regen Med 2013.

Journal of Prosthodontics, Vol 25, No. 4 (June 2016): pg. 310-318. DOI. This article is @ Wiley and permission has been granted for this version to appear in e-Publications@Marquette. Wiley does not grant permission for this article to be further copied/distributed or hosted elsewhere without the express permission from Wiley. 
NOT THE PUBLISHED VERSION; this is the author's final, peer-reviewed manuscript. The published version may be accessed by following the link in the citation at the bottom of the page.

${ }^{107}$ Duan B, Wang M, Zhou WY, et al: Three-dimensional nanocomposite scaffolds fabricated via selective laser sintering for bone tissue engineering. Acta Biomater 2010;6:4495-4505

${ }^{108}$ Duan B, Wang M: Customized Ca-P/PHBV nanocomposite scaffolds for bone tissue engineering: design, fabrication, surface modification and sustained release of growth factor. J $R$ Soc Interface 2010;7:S615S629

${ }^{109}$ Wiria FE, Shyan JYM, Lim PN, et al: Printing of titanium implant prototype. Mater Design 2010;31:S101-S105

${ }^{110}$ Ryan GE, Pandit AS, Apatsidis DP: Porous titanium scaffolds fabricated using a rapid prototyping and powder metallurgy technique.

Biomaterials 2008;29:3625-3635

${ }^{111} \mathrm{Al}$ Ruhaimi KA: Bone graft substitutes: a comparative qualitative histologic review of current osteoconductive grafting materials. Int J Oral Maxillofac Implants 2000;16:105-114

${ }^{112}$ Head WC, Bauk DJ, Emerson JrRH: Titanium as the material of choice for cementless femoral components in total hip arthroplasty. Clin Orthop Relat Res 1995;311:85-90

${ }^{113} \mathrm{Li} \mathrm{JP}$, de Wijn JR, Van Blitterswijk CA, et al: Porous Ti 6 Al $4 \mathrm{~V}$ scaffold directly fabricating by rapid prototyping: preparation and in vitro experiment. Biomaterials 2006;27:1223-1235

${ }^{114}$ Olivier V, Faucheux N, Hardouin P: Biomaterial challenges and approaches to stem cell use in bone reconstructive surgery. Drug Discov Today 2004; $9: 803-811$

${ }^{115}$ Yang $\mathrm{S}$, LeongK-F, Du Z, et al: The design of scaffolds for use in tissue engineering. Part II: Rapid prototyping techniques. Tissue Eng 2002;8:1-11

${ }^{116}$ Seitz H, Rieder W, Irsen S, et al: Three-dimensional printing of porous ceramic scaffolds for bone tissue engineering. J Biomed Mater Res $B$ Appl Biomater 2005; 74:782-788

${ }^{117}$ Dhariwala $B$, Hunt $E$, Boland T: Rapid prototyping of tissue-engineering constructs, using photopolymerizable hydrogels and stereolithography. Tissue Eng 2004;10:1316-1322

${ }^{118}$ BhumiratanaS, Vunjak-Novakovic G: Concise review: personalized human bone grafts for reconstructing head and face. Stem Cells Transl Med 2012;1:64-69

${ }^{119}$ Pereira MM, Jones JR, Hench LL: Bioactive glass and hybrid scaffolds prepared by sol-gel method for bone tissue engineering. Adv Appl Ceram 2005;104:35-42

Journal of Prosthodontics, Vol 25, No. 4 (June 2016): pg. 310-318. DOI. This article is @ Wiley and permission has been granted for this version to appear in e-Publications@Marquette. Wiley does not grant permission for this article to be further copied/distributed or hosted elsewhere without the express permission from Wiley. 